DOI:

УДК 621.899:519.87

В.Д. Вернигора, старший викладач,vernyhora.viktor@gmail.com

О.М. Коробочка, д.т.н., професор, ekorobochra@ukr.net

В.С. Авер'янов, к.т.н., доцент, averynov@ukr.net

Ю.А. Коржавін, к.т.н., доцент, corua@ukr.net

Дніпровський державний технічний університет, м. Кам'янське

\title{
МАТЕМАТИЧНА МОДЕЛЬ ПРОЦЕСУ ОЧИЩЕННЯ ВОДНИХ РІДИН ВІД МЕХАНІЧНИХ ДОМІШОК
}

На підставі експериментальних даних розроблена математична модель для визначення часу стабільного фільтрування рідини через тканину бязь по поверхні фільтрувальної перегородки як функиії від сукупності режимних параметрів безкамерного очищення. Встановлено, що найбільший вплив на час стабільного фільтрування рідини через перегородку тканини бязь має витрати забрудненої рідини, співвідношення витрат тангенціального і осьового потоків рідини, вхідна концентрачія забруднення.

Ключові слова: час фільтрування; рідина; математична модель; механічні домішки; режимні параметри.

On the basis of experimental data has developed a mathematical model to determine the time of the stable filter fluid through the fabric of the clothing on the surface of the filter septum as a function of aggregate operational parameters of a tubeless tire. Found that the greatest impact at the time of the stable filter fluid through the wall of tissue fluid has contaminated clothing expenses, the ratio of the cost tangencialnogo and axial flow fluid input concentration of pollution.

Keywords: filter; fluid; mathematical model; mechanical impurities; the security settings.

\section{Постановка проблеми}

Технологічні виробничі процеси пов'язані з використанням і забрудненням водних технологічних середовищ. При механічній обробці металів використовуються мастильні охолоджувальні рідини на водній основі. При митті автомобілів використовуються водні технологічні рідини: технологічна вода; мийні розчини для миття автомобілів; спеціальні мийні розчини для миття агрегатів, вузлів, механізмів і деталей автомобілів.

3 точки зору очищення, забруднені водні технологічні середовища містять забруднюючі речовини щільністю більше $10^{3} \mathrm{\kappa} / \mathrm{m}^{3}$. Речовинами щільністю більше $10^{3} \mathrm{\kappa r} / \mathrm{m}^{3}$ можуть бути: дрібноелементна стружка, шлами, пісок, глина, гравій і ін. [1]. Основним забруднювачем водних технологічних середовищ $\epsilon$ механічні домішки. Проблема очищення водних середовищ від механічних домішок, які використовуються в технологічних процесах на промислових підприємствах, стоїть дуже гостро та потребує прийняття невідкладних інженерних рішень.

\section{Аналіз останніх досліджень і публікацій}

Для очищення забруднених водних технологічних середовищ перед повторним використанням або скиданням їх у водойми або каналізацію застосовуються наступні основні способи очищення: гравітаційне очищення; відцентрове очищення; магнітна сепарація; флотація; фільтрування [2-3].

Гравітаційне очищення здійснюється у відстійниках $[4,5]$. Відстійники як самостійні очисники застосовуються рідко. Вони застосовується для відділення із забруднених водних технологічних середовищ нерозчинених мінеральних і органічних домішок. Основними недоліками гравітаційного очищення $є$ : низька швидкість очищення рідин від механічних домішок; великі габаритні розміри;значні витрати ручної праці при їх обслуговуванні.

На сьогоднішній день методом очищення від будь-яких видів механічних забруднень на фільтрувальних установках є найбільш ефективним [6-8]. Фільтруванням називають процес відділення механічних домішок за допомогою пористих перегородок. В якості фільтрувальної перегородки використовуються металеві сітки, фільтрувальні тканини, фільтрувальний папір і 
порошки. До недоліків цих фільтрувальних пристроїв слід віднести значну металоємність і складність виготовлення, переривчасту дію більшої частини фільтрувальних установок, великі габаритні розміри.

Процес очищення водних середовищ від механічних домішок розглянуто в роботах [9-12]. Авторами запропоновано використання енергії закрученого вільного струменя рідини. Використання даної технології дозволяє створити безкамерні фільтрувальні установки спрощеної конструкції. Вони дозволяють вести процес очищення рідини від механічних домішок 3 ступенем очищення до 90-95\%. Але проблемою є коливання продуктивності процесу фільтрування при очищені технологічних рідин (забруднення фільтрувальної перегородки призводить до зменшення продуктивності процесу очищення).

Зважаючи на це, актуальним завданням щодо подальшого удосконалення процесу безкамерного фільтрування є встановлення залежності часу стабільної працездатності фільтрувального матеріалу, вибір і обгрунтування сукупності геометричних та режимних параметрів процесу очищення.

\section{Формування мети дослідження}

Метою роботи є моделювання процесу очищення водних рідин від механічних домішок на безкамерних фільтрувальних установках $з$ отриманням математичної залежності часу стабільного фільтрування рідини при різних режимних параметрах безкамерної фільтрованої установки.

\section{Виклад основного матеріалу}

В замкнених водозворотних системах експлуатації водних технологічних рідин основною проблемою $\epsilon$ забезпечення постійної продуктивності процесу очищення рідини від механічних домішок. Для забезпечення постійності продуктивності процесу очищення необхідно визначити максимальний час роботи фільтрувальної перегородки.

У роботі поставлено завдання про визначення часу стабільного фільтрування рідини 3 допомогою перегородки з тканини бязь.

Завдання вирішувалося знаходженням умовного мінімуму функції відгуку для часу ста-

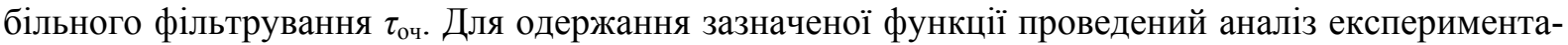
льних даних технологічного процесу.

Для визначення впливу концентрації твердих частинок в рідині на продуктивність процесу безкамерного фільтрування проводили виміри за часом при концентрації забруднень від

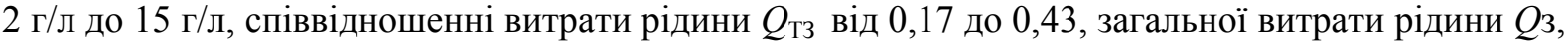
від 0,5 до 1,0 л/с. При проведенні експериментальних досліджень використовувалась в якості матеріалу фільтрувальної перегородки тканина бязь 3 коефіцієнтом опору $\xi_{\text {p.n. }}=1-\frac{0,0016}{0,00236}=0,32$.

Для побудови математичної моделі залежності часу стабільного фільтрування рідини $\tau_{\text {оч }}=f\left(Q_{3}, Q_{3} / Q_{\mathrm{T}}, k_{\mathrm{BX}}\right)$ від витрати забрудненої рідини через сопло $Q_{3}$; від відношення витрат рідини через тангенціально врізаний патрубок і через сопло $Q_{\mathrm{T}} / Q_{3}$ (далі $Q_{\mathrm{T} 3}$ ); від вхідної концентрації забруднення $k_{\mathrm{BX}}$ У вигляді ступеневого поліному другого порядку реалізований центральний композиційний ротатабельний план другого порядку для трьох факторів. Рівні варіювання факторів представлені в табл. 1.

Загальна кількість досліджень у матриці центрального композиційного ротатабельного плану при $\kappa=3$ факторах склала [13]:

$$
N=2^{\kappa}+2 \kappa+n_{0}=2^{3}+2 \cdot 3+6=20,
$$

де $n_{0}$ - кількість експериментів в центрі плану з нульовими координатами.

Матриця планування і результати дослідження наведені у табл. 2. 
Таблиия 1. Рівні та інтервали варіювання факторів

\begin{tabular}{|c|c|c|c|c|c|c|c|}
\hline \multirow[b]{2}{*}{ Фактори } & \multirow{2}{*}{$\begin{array}{c}\text { Кодове } \\
\text { позна- } \\
\text { чення }\end{array}$} & \multirow{2}{*}{$\begin{array}{c}\text { Інтер- } \\
\text { вали } \\
\text { варію- } \\
\text { вання }\end{array}$} & \multicolumn{5}{|c|}{ Рівні факторів } \\
\hline & & & $-1,682$ & -1 & 0 & +1 & $+1,682$ \\
\hline $\begin{array}{l}\text { Загальна витрата рідини } \\
Q_{\text {заг, }}, \text { л/с }\end{array}$ & $x_{1}$ & 0,253 & 0,33 & 0,5 & 0,75 & 1,0 & 0,52 \\
\hline $\begin{array}{l}\text { Співвідношення витрати } \\
\text { рідини } Q_{\text {T3 }}\end{array}$ & $x_{2}$ & 0,13 & 0,1 & 0,17 & 0,3 & 0,43 & 0,52 \\
\hline $\begin{array}{l}\text { Вхідна концентрація забруд- } \\
\text { нення маслами } k_{k x}, \Gamma / л\end{array}$ & $x_{3}$ & 5 & 2 & 5 & 10 & 15 & 18 \\
\hline
\end{tabular}

Таблиия 2. Матриця планування і результати дослідження

\begin{tabular}{|c|c|c|c|c|c|c|c|c|c|c|c|c|c|}
\hline $\begin{array}{c}\text { № до- } \\
\text { слід. }\end{array}$ & $x_{0}$ & $x_{1}$ & $x_{2}$ & $x_{3}$ & $x_{1} x_{2}$ & $x_{1} x_{3}$ & $x_{2} x_{3}$ & $x^{2}{ }_{1}$ & $x_{2}{ }_{2}$ & $x_{3}{ }_{3}$ & $y_{\text {досл }}$ & $y_{p}$ & $\begin{array}{c}\text { Похиб- } \\
\text { ка, } \\
\%\end{array}$ \\
\hline 1 & 1 & 1 & 1 & 1 & 1 & 1 & 1 & 1 & 1 & 1 & 82 & 82,1 & 0,12 \\
\hline 2 & 1 & 1 & 1 & -1 & 1 & -1 & -1 & 1 & 1 & 1 & 184 & 184,2 & 0,08 \\
\hline 3 & 1 & 1 & -1 & 1 & -1 & 1 & -1 & 1 & 1 & 1 & 155 & 154,6 & 0,23 \\
\hline 4 & 1 & 1 & -1 & -1 & -1 & -1 & 1 & 1 & 1 & 1 & 294 & 294,7 & 0,23 \\
\hline 5 & 1 & -1 & 1 & 1 & -1 & -1 & 1 & 1 & 1 & 1 & 81 & 80,7 & 0,36 \\
\hline 6 & 1 & -1 & 1 & -1 & -1 & 1 & -1 & 1 & 1 & 1 & 68 & 68,7 & 1,1 \\
\hline 7 & 1 & -1 & -1 & 1 & 1 & -1 & -1 & 1 & 1 & 1 & 15 & 15,2 & 1,63 \\
\hline 8 & 1 & -1 & -1 & -1 & 1 & 1 & 1 & 1 & 1 & 1 & 41 & 41,3 & 0,7 \\
\hline 9 & 1 & 1,68 & 0 & 0 & 0 & 0 & 0 & 2,83 & 0 & 0 & 250 & 250,1 & 0,06 \\
\hline 10 & 1 & $-1,68$ & 0 & 0 & 0 & 0 & 0 & 2,83 & 0 & 0 & 36 & 35,8 & 0,27 \\
\hline 11 & 1 & 0 & 1,68 & 0 & 0 & 0 & 0 & 0 & 2,83 & 0 & 100 & 100,1 & 0,02 \\
\hline 12 & 1 & 0 & $-1,68$ & 0 & 0 & 0 & 0 & 0 & 2,83 & 0 & 138 & 137,8 & 0,05 \\
\hline 13 & 1 & 0 & 0 & 1,68 & 0 & 0 & 0 & 0 & 0 & 2,83 & 20 & 20,6 & 2,86 \\
\hline 14 & 1 & 0 & 0 & $-1,68$ & 0 & 0 & 0 & 0 & 0 & 2,83 & 129 & 128,9 & 0,55 \\
\hline 15 & 1 & 0 & 0 & 0 & 0 & 0 & 0 & 0 & 0 & 0 & 62 & 61,6 & 0,66 \\
\hline 16 & 1 & 0 & 0 & 0 & 0 & 0 & 0 & 0 & 0 & 0 & 61 & 61,6 & 0,97 \\
\hline 17 & 1 & 0 & 0 & 0 & 0 & 0 & 0 & 0 & 0 & 0 & 62 & 61,65 & 0,66 \\
\hline 18 & 1 & 0 & 0 & 0 & 0 & 0 & 0 & 0 & 0 & 0 & 62 & 61,6 & 0,66 \\
\hline 19 & 1 & 0 & 0 & 0 & 0 & 0 & 0 & 0 & 0 & 0 & 61 & 61,6 & 0,97 \\
\hline 20 & 1 & 0 & 0 & 0 & 0 & 0 & 0 & 0 & 0 & 0 & 62 & 61,6 & 0,66 \\
\hline
\end{tabular}

Центральний композиційний ротатабельний план другого порядку для трьох факторів складається 3 плану повного факторного експерименту типу $2^{3}$, шести досліджень у «зіркових точках» і шести досліджень в центрі плану. 
За результатами досліджень, виконаних у відповідності 3 прийнятим планом експерименту, можна оцінити коефіцієнти рівняння регресії виду:

$$
y_{p}=b_{0}+b_{1} x_{1}+b_{2} x_{2}+b_{3} x_{3}+b_{12} x_{1} x_{2}+b_{13} x_{1} x_{3}+b_{23} x_{2} x_{3}+b_{11} x_{1}^{2}+b_{22} x_{2}^{2}+b_{33} x_{3}^{2} .
$$

При кількості факторів $\kappa=3$ коефіцієнти рівняння регресії (2), які розраховано за формулами [14], становлять:

$$
\begin{array}{rlrl}
b_{0} & =61,6 ; \quad b_{1}=63,7 ; & b_{2}=-11,3 ; \quad b_{3}=-32 ; \\
b_{12} & =-34,5 ; \quad b_{13}=-28,5 ; & b_{23}=9,5 ; & \\
b_{11} & =28,8 ; \quad b_{22}=20,3 ; & b_{33} & =4.5 .
\end{array}
$$

Дисперсію $s_{y}^{2}$ відтворюваності визначаємо за результатами дослідження в центрі плану (табл. 2).

$$
s_{y}^{2}=\frac{\sum\left(y_{j}-\bar{y}_{j}\right)^{2}}{n_{0}-1}=0,27 .
$$

Дисперсії, що характеризують помилки в визначенні коефіцієнтів рівняння регресії, згідно [14] при $\kappa=3$ становлять:

$$
\begin{array}{ll}
S^{2}\left\{b_{0}\right\}=0,0444 ; & S^{2}\left\{b_{i}\right\}=0,0195 ; \\
S^{2}\left\{b_{i l}\right\}=0,0333 ; & S^{2}\left\{b_{i i}\right\}=0,0185 .
\end{array}
$$

Довірчі інтервали для коефіцієнтів рівняння регресії (2):

$$
\begin{aligned}
& \Delta b_{0}= \pm t \cdot S\left\{b_{0}\right\}= \pm 0,54 ; \\
& \Delta b_{i}= \pm t \cdot S\left\{b_{i}\right\}= \pm 0,36 ; \\
& \Delta b_{i l}= \pm t \cdot S\left\{b_{i l}\right\}= \pm 0,47 ; \\
& \Delta b_{i i}= \pm t \cdot S\left\{b_{i i}\right\}= \pm 0,35,
\end{aligned}
$$

де $\pm t=2,57$ - табличне значення критерію Ст'юдента при $5 \%$-му рівні значимості і числом ступеню свободи $f=5$.

При перевірці коефіцієнтів (3) за критерієм Ст'юдента (при 5 \%-му рівні значимості та числі ступеню свободи $f=5$ ) встановлено, що усі коефіцієнти більше довірчого інтервалу, тому вони є значимими і включені до рівняння регресії (2).

В результаті рівняння регресії (2) буде мати вигляд:

$$
\begin{aligned}
& y_{p}=61,6+63,7 x_{1}-11,3 x_{2}-32 x_{3}-34,5 x_{1} x_{2}-28,5 x_{1} x_{3}++9,5 x_{2} x_{3}+28,8 x_{11}^{2}+ \\
& +20,3 x_{22}^{2}+4,54 x_{33}^{2} .
\end{aligned}
$$

Перевірка гіпотези адекватності моделі (6) за критерієм Фішера при 5 \% -му рівні значущості і числах ступенів свободи дисперсії адекватності $f_{a d}=N-k-\left(n_{0}-1\right)=20-10-(6-1)=5$ i дисперсії відтворюваності $f_{y}=n_{0}-1=6-1=5$ показала, що отримана модель адекватна, оскільки розрахункове значення критерію Фішера менше табличного $F_{p}=1,72<F_{T}(0,05 ; 5 ; 5)=5,1$.

Обчислені за рівнянням (6) значення відрізняються від експериментальних на величини, що не перевищують похибку дослідження (табл. 2).

Кодовані значення факторів пов'язані з натуральними наступними залежностями:

$$
\begin{aligned}
& x_{1}=\frac{Q_{3}-0,75}{0,25}=4 Q_{3}-3 ; \\
& x_{2}=\frac{Q_{T 3}-0,3}{0,13}=7,69 Q_{T 3}-2,31 ; \\
& x_{2}=\frac{k_{B x}-10}{5}=0,2 k_{B x}-2 .
\end{aligned}
$$

Тоді рівняння (6) з урахуванням залежностей (7) має вигляд: 


$$
\begin{aligned}
& \tau_{\text {оч }}=-19,1+109,8 Q_{3}-158,56 Q_{T 3}+2,62 k_{B x}-1061,2 Q_{3} Q_{T 3}-22,72 Q_{3} k_{B x}+ \\
& +14,63 Q_{T 3} k_{B x}+460,8 Q_{3}^{2}+1200,5 Q_{T 3}^{2}+0,182 k_{B x}^{2} .
\end{aligned}
$$

Рівняння (8) адекватне, тому його можна використовувати як інтерполяційну формулу для обчислення величини $\tau_{\text {оч}}$, (сек.) - часу стабільного фільтрування рідини від механічних домішок.

За результатами розрахунків за рівнянням (8) побудовані графіки (рис. 1-3) залежності

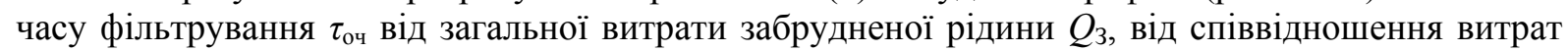

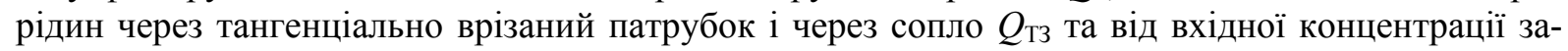
бруднення домішками $k_{6 x}$.

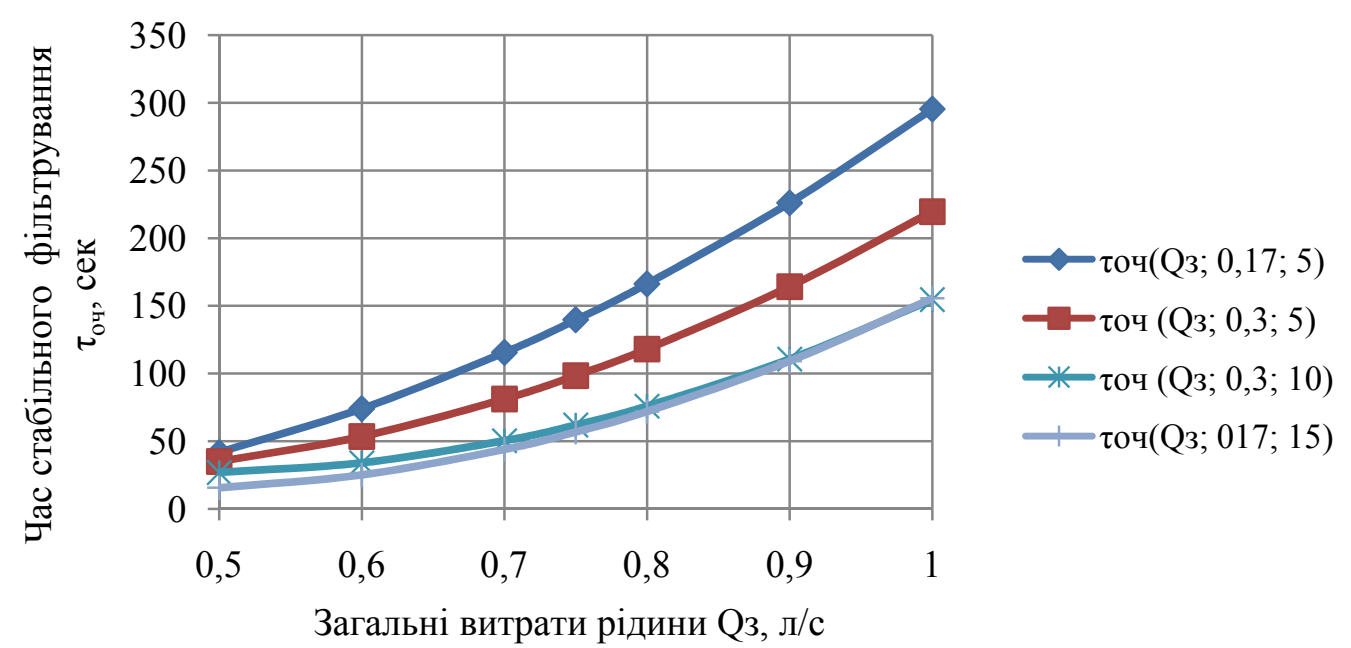

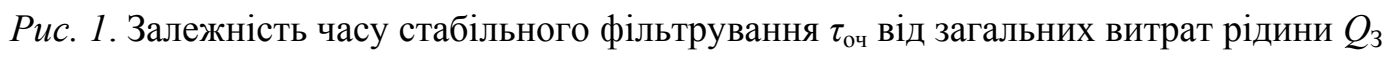

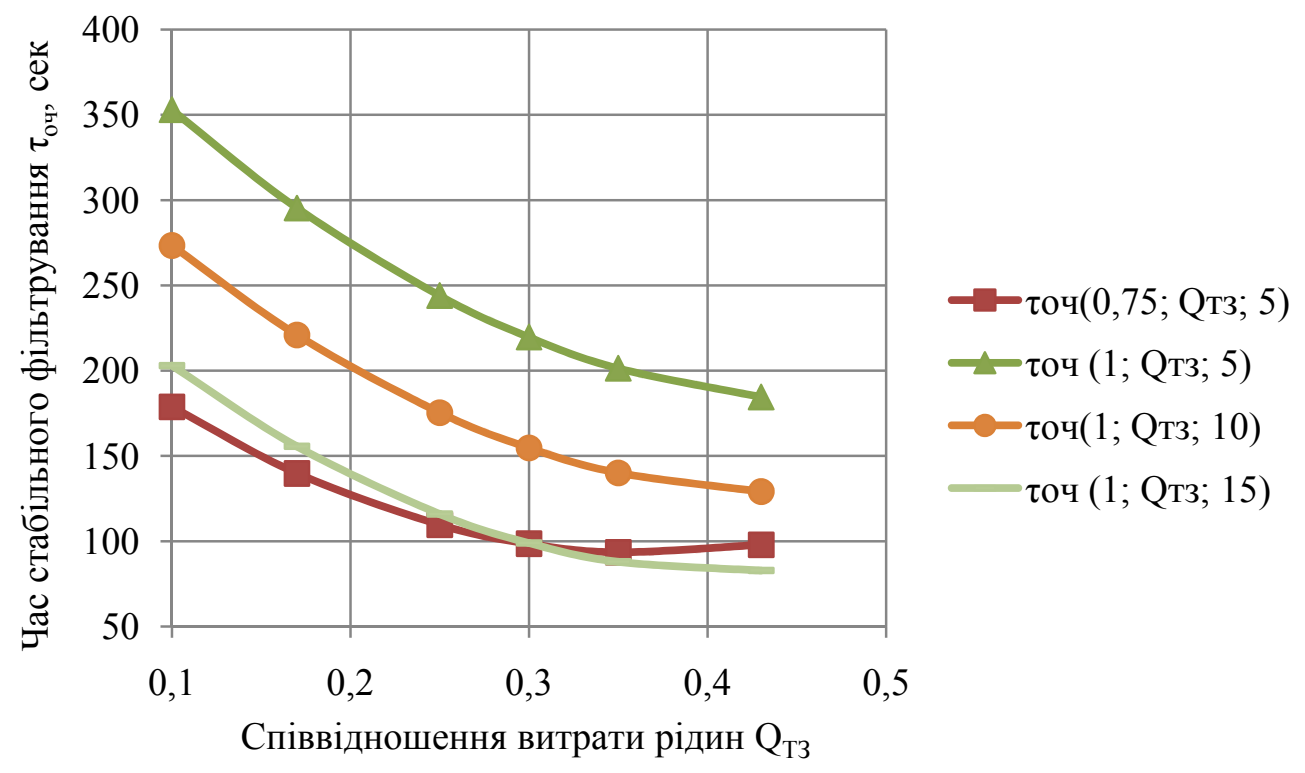

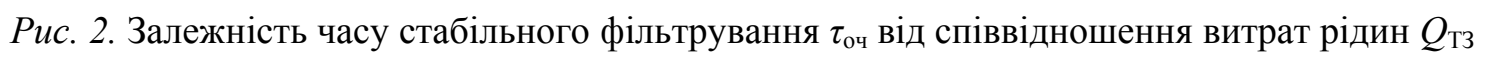




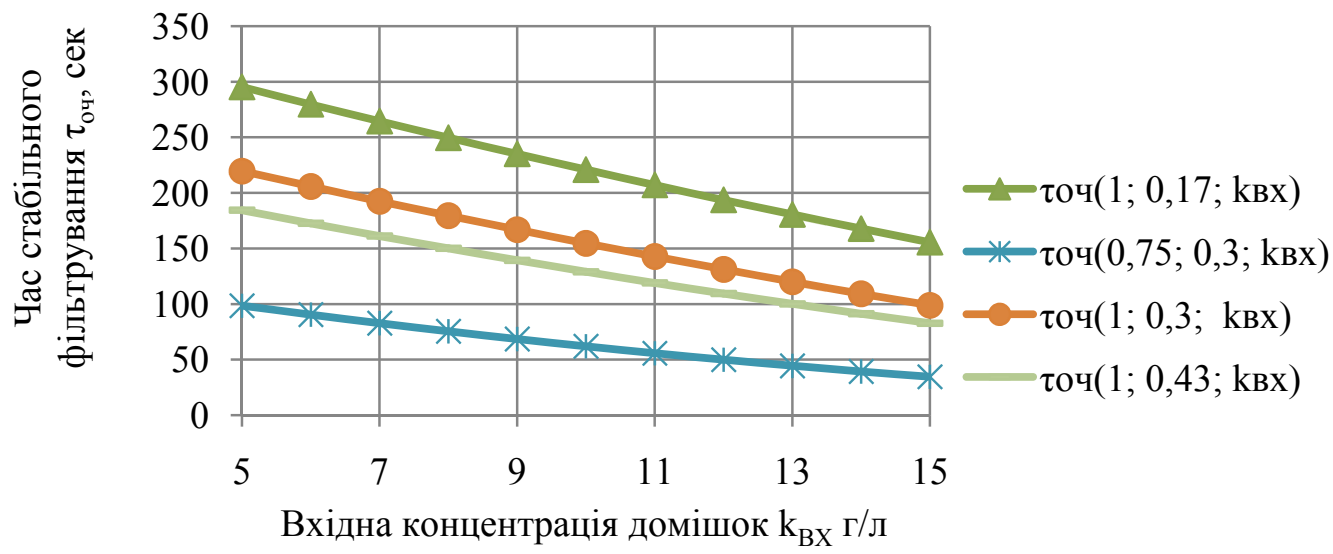

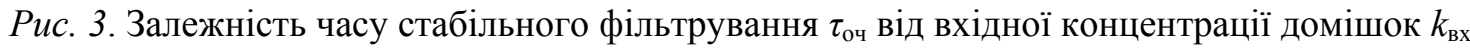

Відповідно отриманим залежностям (рис. 1-3) встановлено, що час стабільного фільтрування рідини через перегородку з тканини бязь збільшується при збільшені загальної витрати забрудненої рідини $Q_{3}$ і зменшується при збільшені співвідношення витрат рідин через танген-

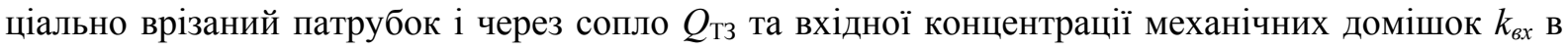
рідині.

\section{Висновки}

За результатами проведених досліджень отримана математична залежність для визначеннячасу стабільного фільтруваннярідини через тканину бязь по площині фільтрувальної перегородки. Це дозволяє визначити ефективні режимні параметри безкамерної фільтрувальної установки, що впливають на продуктивність процесу фільтрування рідини.

\section{Список використаної літератури}

1. Коробочка О. М. Прогресивні способи знезараження та знешкодження МОР металорізальних верстатів. Монографія / Коробочка О. М., Тихонцов О. М., Павленко А. М. - Дніпродзержинськ, 1994. - 160 с.

2. Журба М. Г. Разработка и внедрение водоочистных комплексов поверхностного стока / М. Г. Журба, Ж. М. Говорова, О. Б. Говоров и др. // Водоснабжение и сан. техника. - 2003. - № 3. - С. 25-29.

3. Запольський А. К. Водопостачання, водовідведення та якість води / Запольський А. К. - К.: Вища школа, 2005. - 671 с.

4. Пискунов В. М. Горизонтальные водопроводные отстойники / Пискунов В. М. - М.: Госстройиздат, 1995. - $120 \mathrm{c}$.

5. Современные технологии и оборудование для обработки воды на водоочистных станциях / [под ред. Орлов М. П.]. - М.: НИИ КВОВ, 1997. - 112 с.

6. Яковлев С. В. Водоотведение и очистка сточных вод. / С. В. Яковлев, Ю. В. Воронов. - М.: $\mathrm{ACB}, 2002 .-704 \mathrm{c}$.

7. Слипченко В.А. Совершенствование технологии очистки воды фильтрованием / В.А. Слипченко // Киев: ИПК Госжилкомхоза УССР, 1991. 67 с.

8. Tao D., Groppo J.G., Parekh B.K. Effects of vacuum filtration parameters on ultrafine coal dewatering. Coal Preparation. 2000, v. 21, p. 315-335.

9. Аверьянов В.С. Определение производительности бескамерной фильтровальной установки / В.С. Аверьянов, Л.А. Олейник, А.Н. Коробочка, А.В. Романюк // Сборник научных трудов Керченского государственного морского технологического университета. - 2009. - № 10. C. $158-163$. 
10. Аверьянов В. С. Методика расчета бескамерных фильтровальных устройств / В. С. Аверьянов, А. Н. Коробочка, Д. Е. Белоус // Сборник научных трудов Керченского государственного морского технологического университета. - 2012. - № 13. - С. 10-14.

11. Авер'янов В. С. Екологічно чиста технологія безкамерного очищення водних технологічних середовищ від механічних домішок / В. С. Авер'янов, О. М. Коробочка, А. В. Пасенко // Вісник КрНУ імені Михайла Остроградського. - 2012. - Вип. 6 (77). - С. 117-119.

12. Використання безкамерної фільтрувальної установки для очищення рідини на автотранспортних підприємствах Наукові праці. Вип. 191. Т. 203. Техногенна безпека. - Миколаїв: ЧДУ ім. Петра Могили. 2012. - С. 17-21, Коробочка О.М.

13. Спиридонов А. А. Планирование эксперимента при исследовании технологических процессов / А. А. Спиридонов // М.: Машиностроение, 1981. 184 с.

14. Шкляр В. Н. Планирование эксперимента и обработка результатов / В. Н. Шкляр // Томск: ТПУ, 2010. 90 c.

\title{
MATHEMATICAL MODEL FOR THE PROCESS OF WATER LIQUID CLEANING FROM MECHANICAL HOUSES \\ Vernyhora V., Korobochka A., Averyanov V., Korzhavin Iu.
}

\begin{abstract}
Technological production processes are associated with the use and pollution of water technology environments. When machining metals used lubricating cooling liquids on a water basis. When washing cars, water-based process liquids are used: process water; washing solutions for washing cars; special washing solutions for the washing of aggregates, knots, mechanisms and parts of cars.

From the point of view of purification, contaminated water process environments contain pollutants: fine-element chips, sludge, sand, clay, gravel, and others. The main pollutant of water process environments are mechanical impurities. The problem of cleaning water environments from mechanical impurities, which are used in technological processes at industrial enterprises, is very urgent and requires the adoption of urgent engineering decisions.

For purification of contaminated aqueous technological environments, the following basic methods of purification are used before reusing or discharging them into a reservoir or sewage system: gravity purification; centrifugal purification; magnetic separation; flotation; filtering.

The purpose of the work is to simulate the process of purifying water liquids from mechanical impurities on tubeless filtration plants with the mathematical dependence of the time of stable liquid filtration under different operating parameters of a tubeless filtered installation.

The urgent task for further improvement of the process of tubeless filtration is to determine the time dependence of the stable performance of the filter material, the choice and justification of the set of geometric and regime parameters of the purification process.

In the closed water-repellent systems of operation of water technological liquids the main problem is to ensure the constant productivity of the process of cleaning the liquid from mechanical impurities. To ensure the continuity of the process of cleaning process, it is necessary to determine the maximum time of the filtering partition. The task is to determine the time of stable liquid filtration with the help of a partition of cloth bean.

According to the results of the studies obtained mathematical dependence to determine the time of stable filtration liquor through the cloth bean on the plane of the filter partition. This allows us to determine the effective mode parameters of a tubeless filtration system that affects the performance of the fluid filtering process.
\end{abstract}

\section{References}

[1] Korobochka, O., Tuxonczov, O., Pavlenko, A. (1994). Progresyvni sposoby znezarazhennya ta zneshkodzhennya MOR metalorizalnyx verstativ. Dniprodzerzhunsk:DDTU. 160. 
[2] Zhurba, M., Govorova, Zh., Govorov, O. (2003). Razrabotka i vnedrenie vodoochistnyih kompleksov poverhnostnogo stoka. Vodosnabzhenie i san. tehnika. 3. 25-29.

[3] Zapolskiy, A. (2005). Vodopostachannya, vodovidvedennya ta yakist void. Vischa shkola. 671.

[4] Piskunov, V. (1995). Gorizontalnyie vodoprovodnyie otstoyniki. Gosstroyizdat. 120.

[5] Orlov M. (1997). Sovremennyie tehnologii i oborudovanie dlya obrabotki vodyi na vodoochistnyih stantsiyah. NII KVOV. 112.

[6] Yakovlev, S., Voronov, V. (2002). Vodootvedenie i ochistka stochnyih vod. ASV. 704.

[7] Slipchenko, V. (1991). Sovershenstvovanie tehnologii ochistki vodyi filtrovaniem. Kiev: IPK Goszhilkomhoza. 67.

[8] Tao, D., Groppo, J., Parekh, B. (2000). Effects of vacuum filtration parameters on ultrafine coal dewatering. Coal Preparation. 21. 315-335.

[9] Averyanov, V., Oleynik, L., Korobochka, A., Romanyuk, A. (2009). Opredelenie proizvoditelnosti beskamernoy filtrovalnoy ustanovki. Sbornik nauchnyih trudov Kerchenskogo gosudarstvennogo morskogo tehnologicheskogo universiteta. 10. 158-163.

[10] Averyanov, V., Korobochka, A., Belous, D. (2012). Metodika rascheta beskamernyih filtrovalnyih ustroystv. Sbornik nauchnyih trudov Kerchenskogo gosudarstvennogo morskogo tehnologicheskogo universiteta. 13. 10-14.

[11] Averyanov, V., Korobochka, O., Pasenko, A. (2012). Ekologichno chista tehnologiya bezkamernogo ochischennya vodnih tehnologichnih seredovisch vid mehanichnih domishok. VIsnik KrNU ImenI Mihayla Ostrogradskogo. 6 (77). 117-119.

[12] Averyanov, V., Korobochka, O. (2012). Vikoristannya bezkamernoy fIltruvalnoy ustanovki dlya ochischennya ridini na avtotransportnih pidpriemstvah. Naukovi pratsi. Tehnogenna bezpeka. 191(203). 17-21.

[13] Spiridonov, A. (1981). Planirovanie eksperimenta pri issledovanii tehnologicheskih protsessov. Mashinostroenie. 184.

[14] Shklyar, V. (2010). Planirovanie eksperimenta i obrabotka rezultatov. Tomsk: TPU. 90. 